\title{
The Effects of Climate Change on the Multifunctional Role of Basilicata's Forests: The Effects Induced on Yield and $\mathrm{CO}_{2}$ Absorption
}

\author{
Severino Romano, Luigi Fanelli, Mauro Viccaro, Francesco Di Napoli, \\ and Mario Cozzi
}

\begin{abstract}
The first studies on the possible impact of climate change on European forests and the development of adaptation and mitigation strategies began in the 1990s and resulted in the identification of risk assessment models and forest management tools. The prediction of climate change impacts on forests has been based using the evidence theory or Dempster-Shafer (DS)'s theory, appropriately spatialised. The implemented evidence lines refer to the concepts of vulnerability and resilience. The results of the DS model, applied to the Basilicata region, were utilised to assess the loss in biomass production capacity and $\mathrm{CO}_{2}$ absorption ability of different forest-derived biomasses. The loss in stumpage value and in the estimated $\mathrm{CO}_{2}$ absorption shows a reduction over time of forest system's economic value that is basically higher in 2050 than in 2100. The applied methodological approach has shown that the high degree of spatial and information detail may be helpful to produce good predictions to envisage environmental policy strategies for the monitoring and mitigation of the damages caused by the climate change, with a view to ensuring the ecosystems' capacity to produce positive externalities, including air carbon sequestration capacity.
\end{abstract}

\section{Introduction}

Following the last report of the Intergovernmental Panel on Climate Change (IPCC), the rise in greenhouse gases (GHGs) has increased over the last 10 years more rapidly than over the three previous decades; projections actually indicate a $3.7-4.8^{\circ} \mathrm{C}$ rise in the average temperature by the end of the century, in the absence of real mitigation strategies (IPCC 2014). The main climatic parameters, including

\footnotetext{
S. Romano • L. Fanelli • M. Viccaro • F. Di Napoli • M. Cozzi $(\bowtie)$

School of Agricultural Sciences, Forestry, Food and Environment - SAFE, University of

Basilicata, viale dell'Ateneo Lucano 10, 85100 Potenza, Italy

e-mail: mario.cozzi@unibas.it
} 
the increase in average temperature (Donat et al. 2013), describe worrying scenarios both for humans and for natural systems. The large-scale extreme events (Hanley and Caballero 2012), which have increased over the last few years, are all undeniable signs of climate abnormalities.

The climate components, i.e. rainfall, temperature and winds, are the major elements influencing animal and plant species, by regulating their distribution and density in space and over time (Maron et al. 2014) and by interfering, in general, with the physiology and the behaviour, the life cycle, the geographical distribution and the composition and interaction of complex systems. This also applies to forest systems, where the effects are more substantial as compared to multifunctionality levels (Nijnik and Miller 2013). Woods are actually the major carbon absorption sink and the principal means to contrast climate change (Fu et al. 2014). Therefore, it is essential to avail of appropriate tools to understand the effects on forests and develop the adaptation and mitigation strategies required. Simulation models are the main tool for investigating the climate. These mathematical models can predict the climate pattern by simulating the main physical processes of the earth system and testing their functioning based on the simulations of the past climate compared against recent data. Simulations are run for the possible variations of input parameters that in turn depend on other variables (Nakićenović et al. 2000). However, the quality and quantity of the interactions involved in the climate system vary a lot, so that the results of simulation models are affected by inaccuracies and uncertainties.

This work has produced a dynamic and statistical local climate simulation model based on the combination of downscaling techniques. These methods enable the transfer of results to a more detailed scale (Giorgi and Lionello 2008; Rojas et al. 2013; Jacobeit et al. 2014) and, more specifically, to the territory of Basilicata region, Italy. As a matter of fact, the Mediterranean region, which includes Basilicata, has long been identified, among the various world areas, as one of the major climate change hotspots, i.e. one of the biogeographical regions most sensitive and vulnerable to its effects. The implemented simulation model, projected to 2050 and 2100 based on the SRES A1B scenario of the IPCC (IPCC 2007), has enabled the assessment of the mean status and the possible climate variations on the local scale.

Based on the results obtained using the applied climatic model, the research was directed to assessing the effects induced on forest ecosystems. The loss in forest system multifunctionality attributable to the climate change has been extensively studied over the last few years (Seppälä et al. 2009). In this framework, the evidence theory has been applied to forestry for assessing new adaptive management forms (Ducey 2001; Yousefpour et al. 2013), integrated with the fuzzy approach (Deng et al. 2011), and for the economic quantification of damages (Bernetti et al. 2010; Roberts 2008). For the latter aspect, it is necessary to know the physical impact of climate change and set an economic value to this impact. This is difficult to apply, since in many cases there is no monetary value for all physical damages caused by climate change (Carraro et al. 2007). Forests actually produce different environmental externalities $\left(\mathrm{CO}_{2}\right.$ absorption, protection from erosion, surface runoff control, tourism, biodiversity, etc.) that do not have a market, so they cannot be monetarised. For this reason, starting from the vulnerability and resilience notions, this work has estimated the economic damage 
resulting from the loss in biomass yield and the reduced $\mathrm{CO}_{2}$ absorption by Basilicata's forests. The estimates have concerned three time frames, 2100, 2050 and 2012, as reference years.

\section{Materials and Methods}

Forests and natural systems, in particular, play an important role in rebalancing and absorbing the effects caused by external disturbances, provided their resilience is kept constant. Unluckily, the multifunctional essence of forests is not constant over time, partly due to the climate change. The effects are visible in the variation of growth and yield rates, the changes in the composition of existing species and shift in altitude and latitude, with the subsequent change in the biodiversity level and $\mathrm{CO}_{2}$ absorption function.

The ability to predict events by using climate simulation models can be very helpful to identify action strategies and management techniques aimed at improving the climate change adaptation capacity. The applied methodology, summarised in Fig. 1, basically analyses the concepts of vulnerability and resilience of forest stands, using DS theory.

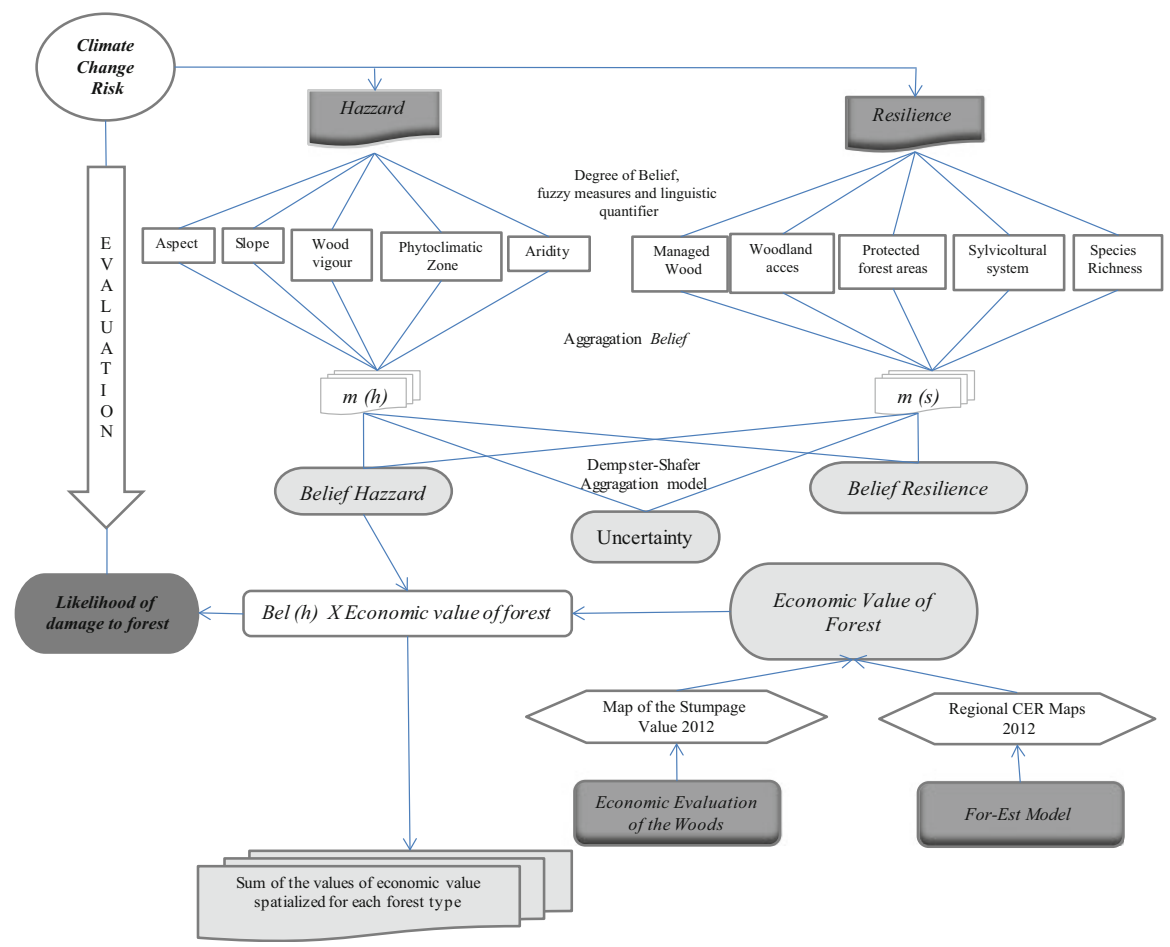

Fig. 1 Model of environmental impact assessment 
Vulnerability is defined as "the degree to which a system is susceptible to, or unable to cope with adverse effects of climate change, including climate variability and extremes" (IPCC 1997), although in the case of forestry, the main factors are the ecological characteristics of species and the morphological traits of the area (Bernetti et al. 2010). Resilience instead has been meant as the capacity of the systems to react to external environmental variations keeping the same structure and the same basic functioning mode (IPCC 1997). Applying the notion of resilience to forests, this may be defined as their capacity to cope with external environmental variations, maintaining some ecological stability, both for the specific composition and the maintenance of the structure, depending on the growth stage of forest (Bernetti et al. 2010). The first step of the work involved the standardisation of the variables that contribute to the resilience and resistance of forest areas, using the Fuzzy Logic (Zadeh 1987). The variables used for the definition of vulnerability and resilience (Fig. 1) have been previously standardised and then grouped, using the DS theory, into three probability indicators:

\section{Belief of vulnerability $[\operatorname{Bel}(h)]$ \\ 2. Belief of resilience $[\operatorname{Bel}(s)]$ \\ 3. Uncertainty $(U ; h, s)$}

The DS theory makes it possible to strengthen knowledge by integrating different kinds of information and distinguishing uncertainty, in order to understand any possible risk associated with decision-making.

The assessment of indicators enabled the estimate of the loss in biomass and in the subsequent stumpage value of Basilicata's forests, by correlating the vulnerability of forest stands with the loss in wood increment. The wood biomass reduction was also assessed and expressed in terms of damage caused by the avoided $\mathrm{CO}_{2}$ fixation by 2050 and 2100 , taking 2012 as reference.

\subsection{The Concept of Plausibility According to Dempster- Shafer's Theory}

Plausibility is a common concept in many situations, ranging from the scientific world to everyday life; it also meets the need to manage and reduce uncertainty. Plausibility can make explicit and formalise given models of appropriate behaviour and reasoning via other conceptual models, such as, for example, the evidence theory.

Coping with uncertainty being the principal objective of plausibility, the DS theory is explicitly targeted at overcoming the limitations of Bayes' conception: as a matter of fact, believing in localization $h$ does not imply necessarily believing in its denial $s$ to the extent of the remaining belief. The DS theory assumes the theoretical possibility to make use of two distinct opposite values to express both belief $h$ and belief $s$. Therefore, taking into account the DS notion of plausibility, we 
can state that, while the $\operatorname{Bel}(h)$ represents the degree of concrete evidence in support of an assumption $h$, the plausibility indicates the degree to which the conditions seem to be adequate for this assumption, although an evidence line in support of it is lacking or difficult to attribute. Hence for any assumption, the $\operatorname{Bel}(h)$ is the lower limit of our commitment, and the plausibility $\operatorname{PLS}(h)$ is the upper limit. The range between the two is the degree of uncertainty to establish either the presence or absence of this assumption.

The assessment of assumptions is based on three key concepts: basic probability assignment (BPA), belief and plausibility. Through the BPA, the DS theory distinguishes clearly the notion of belief from that of plausibility, but it provides an explicit representation in terms of probabilistic functions. The BPA is the contribution of a factor $\left(a_{i}\right)$ to support a specific assumption (e.g. the resilience). In this case, the assessment of the BPA [Eq. (1)] is based on the combination of the fuzzy functions of environmental and socioeconomic variables, weighted via the analytical hierarchy process technique (AHP) (Saaty 1988; Malczewski 2004):

$$
\operatorname{BPA}\left(a_{i} x\right)=\mu_{\mathrm{AHP}}\left(a_{i}\right)^{*} \mu_{a i}\left(x_{a i}\right)
$$

where $\mu_{\mathrm{AHP}}\left(a_{i}\right)$ is the assessment via AHP of the belief of the effect concerning damages to forest stands in the hypothetical scenario of climate change with the variable $\left(a_{i}\right)$ and $\mu_{a i}\left(x_{a i}\right)$ is the assessment of the hypothetical environmental effects of the $a_{i}$ variable in the space $x$. The aggregation for the assumption of vulnerability and resilience to climate changes may be made for pairs of tests, based on their joint probabilities (Shafer 1976). All factors are progressively aggregated by pairs so as to calculate the amount of vulnerable probable mass $m(h)$ and the amount of resilient mass $m(s)$. Once the single BPAs are quantified, the DS technique ratifies the evidence combination procedure (Shafer 1976), updating the belief in the light of the new evidence thanks to the rule of the "orthogonal sum":

$$
\begin{aligned}
& \operatorname{Bel}(h)=\frac{m(h) \cdot(1-m(s))}{1-m(h) \cdot m(s)} \\
& \operatorname{Bel}(s)=\frac{m(s) \cdot(1-m(h))}{1-m(h) \cdot m(s)}
\end{aligned}
$$

The mix of sources results in a forecast that strengthens the belief (Shafer 1976) of $\operatorname{Bel}(h)$ [Eq. (2)] and $\operatorname{Bel}(s)$ [Eq. (3)], already expressed by $m(h)$ and $m(s)$, assuming both sources are equally reliable.

The model aggregates the two evidences $\operatorname{Bel}(h)$ and $\operatorname{Bel}(s)$, which are in conflict with each other, standardises their joint nonconflicting probabilities and determines the uncertainty $U$ intrinsic to the assessment. $U(h, s)$ shows the point where the analysis requires further investigations to clarify the uncertainty. 


\subsection{Estimating the Stumpage Value of Basilicata's Forests}

The stumpage value (SV) is the most likely transformation value of the forest stand. The estimate of the stumpage value is theoretically related to the contributions provided by Serpieri (1917), Cantiani (1957), Patrone (1947), Merlo (1991) and, more recently, Bernetti and Romano (2007). It is the result of an estimate procedure based on some theoretical-methodological assumptions specific to appraisal, and it is targeted at the monetary estimate of the asset. For the determination of the SV, we can focus on two economic appraisal aspects:

- The most likely market value

- The most likely transformation value

The former is determined by direct comparison with the market prices recognised to forest stands that are similar to the one under question, in terms of intrinsic and extrinsic properties (e.g. species, size, site-specific characteristics, etc.), and results directly in the formulation of the value judgement. The latter is based, instead, on an indirect comparison, because the judgement is obtained from simple market data that do not pertain to the asset but to its formation process, so that by subsequent analyses, they enable an estimate judgement. Regardless of the economic appraisal, the applicable procedures may be categorised as:

- Synthetic: visual, comparative and by typical values

- Econometric: the estimate for unit values and by multivariate models

- Analytical: based on the drafting of partial or global business balances

The SV was determined by building the analytical balance of the logging process of standing woody mass till its transformation in assortments. It is based on the drafting of the partial balance, including the market value of production in the assets and the amount of costs required for woody mass transformation till the allocation of products at the landing in the liabilities. The determination of the SV [Eq. (4)] is based on the building of the partial balance of the transformation cycle, in which there are revenues $(R)$ and costs $(C)$ :

$$
\mathrm{SV}=\sum R-\sum C
$$

More specifically, the financial flows that are supposed to occur in the period from the owner's decision to utilise the stand to its conclusion with the inspection of the work performed are all included.

The determination of the balance assets $R$ [Eq. (5)] is derived from the gross marketable production (GMP) and the market price at landing (MPL) for different assortments. For assessing the assets of the stumpage value, bibliographic data (INEA 2012) have been integrated with the prices recorded at landing across the regional area for various assortments. Formally there is: 


$$
R=[\mathrm{GMP} \cdot \mathrm{MPL}]=\sum_{i=1}^{n} \mathrm{PMI}_{i} \cdot Q_{i}
$$

where $Q$ is the volume in $\mathrm{m}^{3}$, obtained directly (dendrometric data) and/or indirectly (scaling tables), and $n$ the types of assortment.

The liabilities of the balance have been obtained by distinguishing the costs [Eq. (6)] of the forest holding (FH) from those of the logging company (LC-thus splitting the transformation process into operational steps) and obtaining the total transformation cost. For the assessment of balance liabilities, bibliographic data (Cozzi et al. 2013) have been integrated with data found out among the forest holdings operating in the region:

$$
K t=\left(\sum_{i=1}^{4} K_{-} \mathrm{FH}_{i}\right)+\left(\sum_{i=1}^{4} K_{-} \mathrm{LC}_{i}\right)
$$

where $K t$ are the total costs of the transformation cycle, $K_{-}$FH the costs charged to the forest holding, $K \_$LC the costs charged to the logging company and $i=1, \ldots$, 4 the steps of the transformation cycle. The costs charged to the owner include all the costs incurred since the decision to cut is taken till the conclusion of cut; they include the costs concerning the administrative procedures (remuneration of forest technicians).

The costs paid by the LC are instead mostly concentrated in the implementing phase. They are traditionally grouped as direct costs (running costs), concerning the remuneration of labour and of the other production factors directly used, and indirect costs (overheads).

Direct costs depend on the organisation of the logging system, the type of expected product, the site-specific characteristics, the distance from the landing/ loading area and the applied extraction technique (short wood system, length wood system and full tree system). In general the items of direct costs are the cost of labour and the running cost/rent of machines.

Overheads include, instead, the costs for management and surveillance; they are often implicit costs, calculated (in per cent) in relation to the other cost items.

Once the assets and liabilities of the balance are identified, a spatialised map of the stumpage value may be obtained for 2012, chosen as reference year. Afterwards, based on forest stand vulnerability values, the SV has been projected to 2050 and 2100, and the loss in biomass income attributable to the climate change has been economically quantified. The stumpage value for future scenarios [Eqs. (7) and (8)] has been calculated in relation to the present stumpage value $\left(\mathrm{SV}_{2012}\right)$, appropriately weighted according to the degree of vulnerability, and assessed for each land unit considered (pixel) using the following equations:

$$
\mathrm{SV}_{2050}=\mathrm{SV}_{2012} \cdot\left(1-\operatorname{Hazard}_{2050}\right)
$$




$$
\mathrm{SV}_{2100}=\mathrm{SV}_{2012} \cdot\left(1-\operatorname{Hazard}_{2100}\right)
$$

The $\mathrm{SV}_{2012}$ has been calculated from the average increases deduced from the scaling tables available for each forest type considered; the increment, which is, in silvicultural terms, an expression of growth of a particular forest system, represents, in economic terms, the increase in value of forest over time. In probabilistic terms, in a scenario of local climate change and subsequent increase in the degree of vulnerability of forests, increments would decline together with the biomass with unfavourable consequences on $\mathrm{CO}_{2}$ absorption.

\subsection{The Economic Evaluation of the Sink Function of Basilicata's Forests}

In Kyoto's Protocol forest, ecosystems are given an important role in the fight against climate change, as they are able to absorb and store carbon and act as a sink of $\mathrm{CO}_{2}$. However, the forest capacity to act as carbon sink is not unlimited: ageing, tree death, natural disasters, etc. result in the release of the previously stored $\mathrm{CO}_{2}$. Among the multiple variables that influence the forest systems' capacity to absorb carbon, climate variations are the major cause. As a matter of fact, the variations of climate act on the biosphere and, in this specific case, on forest systems, both directly and indirectly. Starting from the climate simulation model and the regional forests' vulnerability and resilience values, the variation in $\mathrm{CO}_{2}$ absorption was assessed at three time instants, i.e. 2012, 2050 and 2100, so as to point out the future influence of climate changes on the sink function of regional forests.

Carbon absorption in different forest sinks was estimated by the Forest model (Vitullo et al. 2007; Federici et al. 2008) taking into account the following components (pool) identified by the Good Practice Guidance for land use, land-use change and forestry (IPCC 2003):

- Living biomass including both epigeal and hypogeal parts

- Dead organic matter including the dead matter and litter

- Soils meant as soil organic matter

The forest model enables the quantification of growth in the carbon stored in forests and its subsequent year-to-year variation. $\mathrm{CO}_{2}$ storage was estimated using the regional forest map, drawn by the National Institute of Agricultural Economics (INEA), from the average increases deduced from scaling tables for different species available for Basilicata region. At present the carbon credits generated by the land use, land-use change and forestry (LULUCF) activities have not been incorporated in the European Union Emissions Trading System (EU-ETS), which is the largest cap-and-trade scheme (of carbon credits) in the world (Bonomi et al. 2009; Hamilton et al. 2011). This exclusion means that Removal Units (RMUs) cannot be converted into European Union Allowance (EUA). Due to the 
impossibility of conversion, trading these credits is also inhibited. At the national level, the situation is even more complex because the carbon stored by most Italian forests (both public and private) has been converted by the National Register of agroforest carbon sinks in the corresponding RMUs used by the national government to comply with the obligation of reducing emissions, without providing any remuneration to forest owners, thus confining the sink function to a mere externality of forestry production cycle (Alisciani et al. 2011). The accounting of RMUs prevents forest owners from accessing voluntary markets ${ }^{1}$ as a result of double accounting. At the national level, however, some initiatives, recognised by the National Government, have been undertaken that enable the trading of credits generated by forest activities. ${ }^{2}$ Based on these initiatives, the Certified Emission Reductions (CERs) produced by regional forests and the tradable share in a hypothetical voluntary market have been calculated. The CERs at 2012 were obtained using the following formula:

$$
C_{\mathrm{CO} 2, i}=\left[\left(0.85 * \operatorname{Im}_{i}\right) *\left(1-d_{\mathrm{f}}\right)-U\right] \times 0.5 \times \frac{44}{12}
$$

where $\operatorname{Im}_{i}$ is the annual average increase for each forest type $\left(\mathrm{m}^{3} / \mathrm{ha}\right.$ *year $) ; d_{\mathrm{f}}$ is the reduction coefficient that takes into account the occurrence of any disturbance related to local-scale fires $(d=0.33) ;{ }^{3} U$ is the annual allowable cut, assessed according to the regional regulations and equal to $60 \%$ of the Im for forest trees and $90 \%$ of Im for coppice; 0.5 is the dimensionless conversion factor used to convert dry biomass into carbon (IPCC 2006); and 44/12 is the stoichiometric ratio to convert $\mathrm{C}$ into $\mathrm{CO}_{2} \cdot \mathrm{CO}_{2}$ absorption at 2050 and 2100 was calculated from the values observed for 2012 deducting the fire hazard and based on the possible effects caused by the climate change:

$$
C_{\mathrm{CO} 2, i}=\left[\left(0.85 * \operatorname{Im}_{i}\right) *\left(1-d_{\mathrm{f}, \operatorname{Bel}(h)}\right)-U\right] \times 0.5 \times \frac{44}{12}
$$

where $d_{f, \operatorname{Bel}(h)}$ includes both the risk associated with fires and the estimated vulnerability for forest stands $[\operatorname{Bel}(h)]$.

For the economic estimate of the damage caused by the sink function of regional forests, it has been necessary to analyse the financial markets pertaining to the trading of carbon credits. The diversity of projects, the size and geographical location and the trading market result in wide price variability. The uncertainty associated with the selling price of credits generated by regional forests could be

\footnotetext{
${ }^{1}$ Voluntary markets are widespread in parallel to the regulated market for nonprofit enterprises, associations, public administrations, etc., in order to reduce the GHG emissions of their activities. ${ }^{2}$ Carbomark Project. Available at: http://www.carbomark.org/

${ }^{3}$ The reduction coefficient $d_{\mathrm{f}}$ has been calculated considering the forest areas affected by fires from 2008 to 2013 and the national Law n. 353 of 21 November 2000 "Legge quadro in materia di incendi boschivi" (Framework law on forest fires).
} 
stabilised through the setting up of a regional voluntary market of carbon credits that might fetch a higher price compared to the other trading platforms. This economic mechanism could develop optimally in Basilicata region due to the presence of both market actors. In particular the demand side could be represented by the existing oil-drilling companies that could buy the credits generated by regional forests and partly compensate for the impacts caused by the extraction of fossil fuels. The supply side would be represented by public and private landowners and holders of forest areas through forms of sustainable and certifiable management. This would generate benefits to both market actors: the benefits for demand would involve a greater social acceptance and the possibility of developing a real green marketing strategy, whereas for the supply side, the benefits could be summarised in the increased income-producing activity of forest holdings, the recovery of marginal lands and, last but not least, the improvement in territorial and soil defence (Romano et al. 2013). Based on the above, the selling price of CERs was assumed equal to $45 €$.

\section{Results}

The vulnerability maps ( $\operatorname{Bel}(h)$, Figs. 2 and 3$)$ show the projections obtained for all the region's forest areas. The statistical analysis has pointed out a low risk probability associated with the climate change, 0.09 at 2050 against 0.10 of 2100 , with a time interval between the first and third quartile of 0.10 for 2050 and 0.11 for 2100 . Despite the low risk probability, some regional areas show vulnerability values above 0.5 .

In particular, the forest areas most susceptible to climate change effects are located in the province of Matera, in an area where the increasing levels of aridity

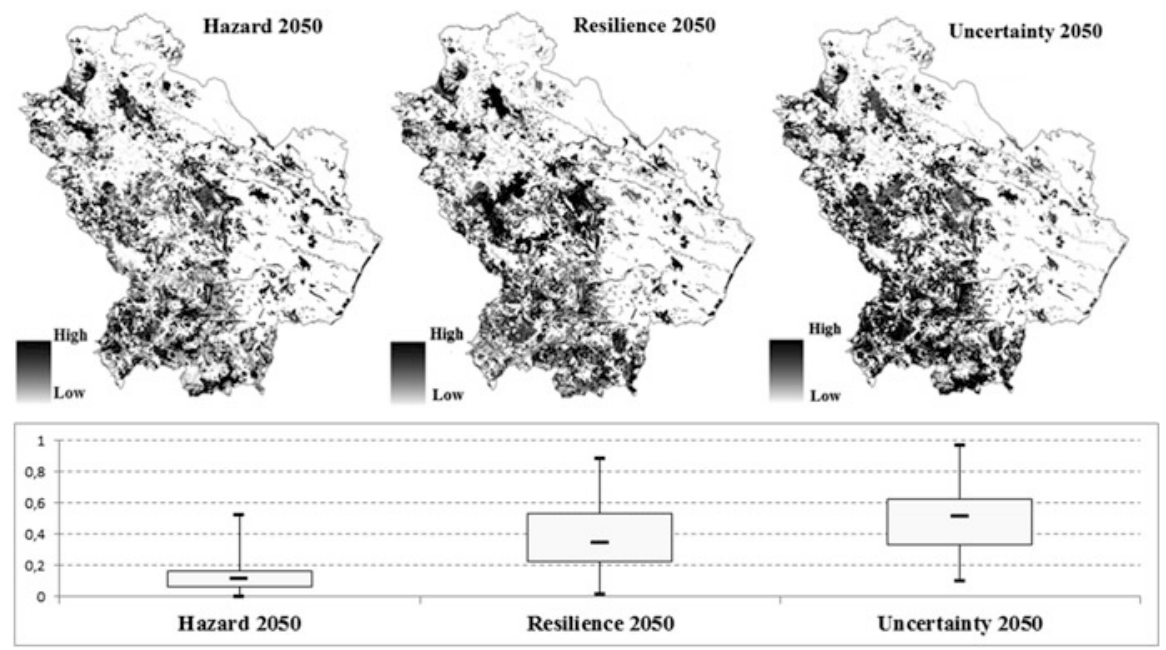

Fig. 2 Vulnerability, resilience and uncertainty maps at 2050 

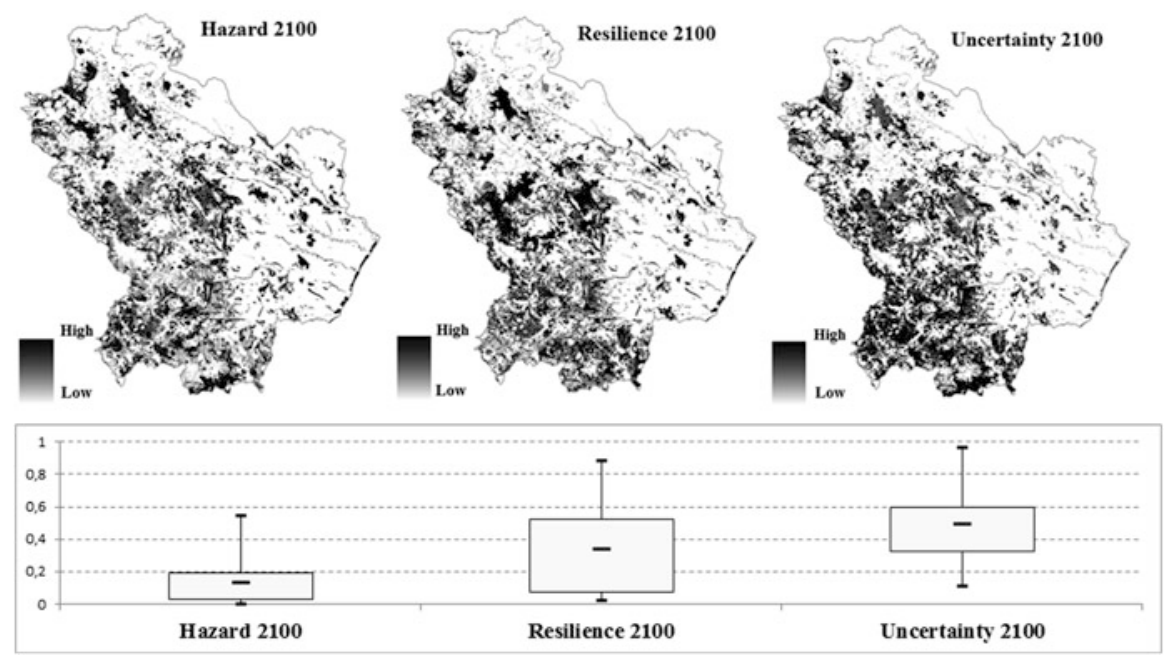

Fig. 3 Vulnerability, resilience and uncertainty maps at 2100

estimated for 2050 and 2100 are the limiting factors to forest vegetation growth. Other susceptible areas are found in the north-west, north-east and south-west parts of the regional territory. For the latter, the problems are mostly related to the poor management of forest resources.

As to the species, higher probability risks will occur in Mediterranean pinewoods, with average values of 0.20 and 0.22 , respectively for 2050 and 2100 . They are followed by spruce groves (Pollino Mountain, spruce plantation of Laurenzana and Ruoti), with an average probability of 0.12 at 2050 and 0.18 at 2100 , and chestnut groves with values ranged between 0.15 of 2050 and 0.16 of 2100 . For all other forest types, the average values are below 0.14 for both reference years. As for the silvicultural system, probability values range between 0.12 at 2050 for coppice of mesophilic-thermophilic broad-leaved trees and 0.22 for chestnut coppice at 2100. For high forest, instead, values fluctuate between 0.08 for beech groves at 2050 and 0.23 for holm oak groves at 2100 .

Depending on the degree of vulnerability observed for different forest-derived types, the SV declines by $15.1 \%$ and $17.6 \%$, respectively, for 2050 and 2100 as referred to 2012. In economic terms, the loss in income and the subsequent damage attributable to the climate change is about 6 million euros for 2050 and 7 million euros for 2100 (Table 1). As for the forest-derived types, the largest variations are found for mesophilic and mesothermophilic oak groves, contrary to the plantations and reforestations that show the lowest variations. The size of damages is of course largely influenced by the extent of areas and the stumpage price of assortments.

The exclusion of forest owners from the carbon market induces to consider the sink function of forest areas as an externality, rather than a forest product, tradable on the market like wood. The problem associated with credit trading and the high price volatility could be solved by the creation of a regional voluntary market. The results regarding the function of $\mathrm{CO}_{2}$ absorption by Basilicata's forest resources 


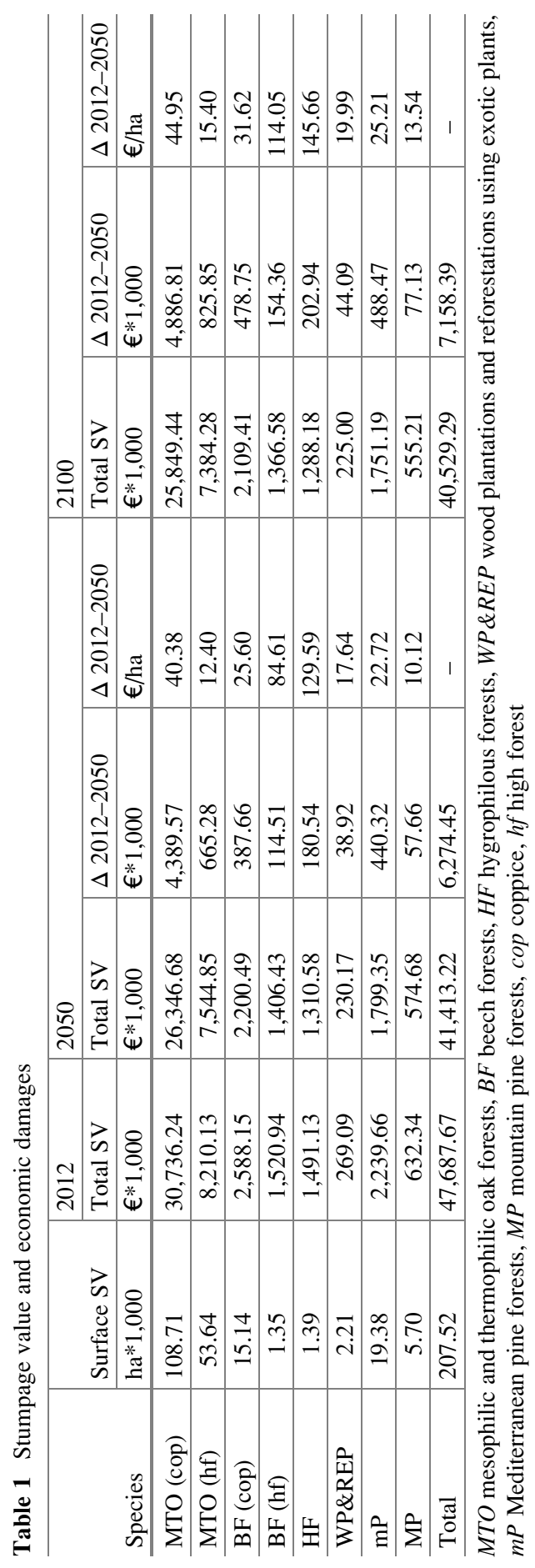


Table $2 \mathrm{CO}_{2}$ absorption for different examined scenarios

\begin{tabular}{l|c|l|l|l|l}
\hline & $\begin{array}{l}\text { Absorption } \\
\mathrm{CO}_{2} 2012\end{array}$ & $\begin{array}{l}\text { Absorption } \\
\mathrm{CO}_{2} 2050\end{array}$ & $\begin{array}{l}\Delta \\
2050-2012\end{array}$ & $\begin{array}{l}\text { Absorption } \\
\mathrm{CO}_{2} 2100\end{array}$ & $\begin{array}{l}\Delta \\
2100-2012\end{array}$ \\
\cline { 2 - 6 } Species & tonne*1,000 & tonne*1,000 & tonne*1,000 & tonne*1,000 & tonne*1,000 \\
\hline $\begin{array}{l}\mathrm{BF} \text { (high } \\
\text { forest) }\end{array}$ & 147.35 & 136.06 & 11.29 & 132.17 & 15.19 \\
\hline $\begin{array}{l}\mathrm{BF} \\
\text { (coppice) }\end{array}$ & 242.77 & 208.11 & 34.66 & 199.75 & 43.02 \\
\hline $\begin{array}{l}\text { TO (high } \\
\text { forest) }\end{array}$ & 476.16 & 438.27 & 37.89 & 428.55 & 47.61 \\
\hline $\begin{array}{l}\text { TO } \\
\text { (coppice) }\end{array}$ & $1,449.30$ & $1,264.26$ & 185.03 & $1,242.36$ & 206.93 \\
\hline $\begin{array}{l}\text { MTO (high } \\
\text { forest) }\end{array}$ & 143.21 & 130.46 & 12.75 & 127.92 & 15.29 \\
\hline $\begin{array}{l}\text { MTO } \\
\text { (coppice) }\end{array}$ & $1,684.71$ & $1,435.08$ & 249.62 & $1,405.43$ & 279.27 \\
\hline $\begin{array}{l}\text { CF (high } \\
\text { forest) }\end{array}$ & 0.31 & 0.28 & 0.03 & 0.28 & 0.03 \\
\hline $\begin{array}{l}\text { CF } \\
\text { (coppice) }\end{array}$ & 388.01 & 310.97 & 77.04 & 304.39 & 83.62 \\
\hline $\begin{array}{l}\text { HO (high } \\
\text { forest) }\end{array}$ & 27.72 & 24.58 & 3.14 & 24.32 & 3.41 \\
\hline $\begin{array}{l}\text { HO } \\
\text { (coppice) }\end{array}$ & 154.40 & 134.27 & 20.13 & 132.45 & 21.95 \\
\hline $\begin{array}{l}\text { MTD (high } \\
\text { forest) }\end{array}$ & 50.79 & 46.80 & 3.99 & 46.48 & 4.31 \\
\hline $\begin{array}{l}\text { MTD } \\
\text { (coppice) }\end{array}$ & 256.20 & 226.09 & 30.10 & 223.09 & 33.11 \\
\hline MP & 73.70 & 66.84 & 6.85 & 64.37 & 9.32 \\
\hline $\begin{array}{l}\text { mP } \\
\text { HF }\end{array}$ & 196.20 & 393.79 & 102.41 & 382.60 & 113.60 \\
\hline WD & 15.52 & 171.31 & 26.29 & 168.09 & 29.52 \\
\hline SF & 2.54 & 2.29 & 0.31 & 0.312 & 0.46 \\
\hline Total & $5,806.50$ & $5,002.58$ & 803.92 & $4,895.42$ & 909.32 \\
\hline
\end{tabular}

TO turkey oak, CF chestnut forests, $H O$ holm oak forests, MTD mesophilic and thermophilic deciduous forests, $S F$ silver fir forests

show a total absorption of about 5.8 million tons at 2012, 5 million for 2050 and 4.8 million at 2100 with a $16 \%$ reduction compared to 2050 and $18.6 \%$ decline in relation to 2100 (Table 2).

In economic terms, this reduction results in a damage amounting to 3.6 and 4.1 million euros, respectively, for 2050 and 2100. In fact the trading of CERs in a hypothetical regional market would produce a benefit of 27.4 million at 2012, 23.7 million at 2050 and 23.2 million at $2100^{4}$ (Table 3).

\footnotetext{
${ }^{4}$ The values shown concerning the SV, the stock of C and CERs refer to the years 2012, 2050 and 2100 and do not represent stored values.
} 
Table 3 CERs generated by the sink activity of regional forests and related variations

\begin{tabular}{|c|c|c|c|c|c|}
\hline & $\begin{array}{l}\text { CERs } \\
2012\end{array}$ & $\begin{array}{l}\text { CERs } \\
2050\end{array}$ & $\begin{array}{l}\text { CERs } \\
2100\end{array}$ & $\begin{array}{l}\text { CERs } \Delta \\
2012-2050\end{array}$ & $\begin{array}{l}\text { CERs } \Delta \\
2012-2100\end{array}$ \\
\hline Species & $€ * 1,000$ & $€ * 1,000$ & $€ * 1,000$ & $€ * 1,000$ & $€ * 1,000$ \\
\hline $\begin{array}{l}\text { BF (high } \\
\text { forest) }\end{array}$ & $1,510.52$ & $1,394.80$ & $1,354.85$ & 115.72 & 155.67 \\
\hline BF (coppice) & 622.16 & 533.33 & 511.92 & 88.83 & 110.24 \\
\hline $\begin{array}{l}\text { TO (high } \\
\text { forest) }\end{array}$ & $4,881.09$ & $4,492.72$ & $4,393.07$ & 388.37 & 488.02 \\
\hline TO (coppice) & $3,714.19$ & $3,239.99$ & $3,183.86$ & 474.20 & 530.32 \\
\hline $\begin{array}{l}\text { MTO (high } \\
\text { forest) }\end{array}$ & $1,468.06$ & $1,337.33$ & $1,311.34$ & 130.74 & 156.72 \\
\hline MTO (coppice) & $4,317.48$ & $3,677.76$ & $3,601.78$ & 639.72 & 715.70 \\
\hline $\begin{array}{l}\text { CF (high } \\
\text { forest) }\end{array}$ & 3.22 & 2.85 & 2.83 & 0.36 & 0.39 \\
\hline CF (coppice) & 994.38 & 796.94 & 780.07 & 197.44 & 214.31 \\
\hline $\begin{array}{l}\mathrm{HO} \text { (high } \\
\text { forest) }\end{array}$ & 284.20 & 252.02 & 249.29 & 32.18 & 34.92 \\
\hline HO (coppice) & 395.69 & 344.10 & 339.44 & 51.59 & 56.24 \\
\hline $\begin{array}{l}\text { MTD (high } \\
\text { forest) }\end{array}$ & 520.68 & 479.74 & 476.47 & 40.94 & 44.21 \\
\hline MTD (coppice) & 656.57 & 579.41 & 571.72 & 77.15 & 84.85 \\
\hline MP & 755.43 & 685.21 & 659.88 & 70.23 & 95.55 \\
\hline $\mathrm{mP}$ & $5,086.54$ & $4,036.74$ & $3,922.06$ & $1,049.80$ & $1,164.48$ \\
\hline $\mathrm{HF}$ & $2,025.68$ & $1,756.13$ & $1,723.90$ & 269.55 & 302.59 \\
\hline WP & 159.07 & 134.83 & 131.65 & 24.23 & 27.42 \\
\hline $\mathrm{SF}$ & 26.05 & 22.85 & 21.33 & 3.21 & 4.72 \\
\hline Total & $27,421.02$ & $23,766.77$ & $23,234.65$ & $3,654.25$ & $4,186.37$ \\
\hline
\end{tabular}

\section{Conclusions}

The high degree of variability and uncertainty of climate changes has induced the European Union, through the 2009 White Paper, to ask the member states to develop mitigation and adaptation strategies, with special reference to forestry and agriculture. In particular, for forestry, mitigation strategies should take into account appropriate adaptation measures to reduce the vulnerability of forest ecosystems in relation to the climate change, while emphasising the role of forests in local economies. The methodology applied in this work has shown that a high degree of spatial and information detail can actually be a good starting point for future environmental policies on the monitoring and mitigation of damages caused by climate change. In fact, the use of methodologies associated with the use of fuzzy approach of the evidence theory are effective tools for data integration, forecasts and assessment of the impacts caused by climate change. The applied approach provides a forecast of forest vulnerability, as well as the economic 
quantification of the impacts induced by a decline in productivity and, as a consequence, in the sink function.

It results that the mountain and sub-mountain areas of the region show the highest vulnerability values, in particular for the species definitely mesophilic, especially coppiced chestnut groves, mesophilic and thermophilic oak forests and Turkey oak plantations. Higher vulnerability has also been found in monospecific Mediterranean pine forests along the Ionian coastal areas. Lower vulnerability levels are found for the formations falling within the protected areas and reforested pinewoods. The greater vulnerability observed for some forest formations leads to a reduction of the forest economic value. In fact, the analysis on stumpage value and carbon absorption shows an overall damage-attributable to the climate changeequal to $9,928,705.94 €$ for 2050 and $11,344,760.80 €$ for 2100 as compared to 2012 .

To prevent, reduce and/or contrast the problems affecting forest resources, a preventive approach would be recommended involving an active human action, aimed at enhancing and strengthening the adaptation capacity of environmental systems and minimising the adverse effects. For low-resilience populations, specific silvicultural actions could be envisaged that might contribute to improve the ecological-functional levels of forests. To this end, it would be advisable to apply treatments aimed at increasing interspecific diversification, increase appropriately the amounts of biomass by extending the turnover and favour the conversion of monospecific non-native species into native species in the typical systems of local vegetation forms.

The major limitation encountered is associated with the components of the economic value that is looked for. Actually it is largely known that the forest, meant as mixed asset, accomplishes other tasks that are not directly measurable within the market. In this framework, it is hoped that the research will be extended to explore the values associated with further services provided by forest areas, with a view to identifying the overall impacts and proposing new planning tools.

Open Access This chapter is distributed under the terms of the Creative Commons Attribution Noncommercial License, which permits any noncommercial use, distribution, and reproduction in any medium, provided the original author(s) and source are credited.

\section{References}

Alisciani F, Carbone F, Perugini L (2011) Criticità e problematiche nella prospettiva post-2012 per la partecipazione del settore forestale all'eventuale mercato nazionale dei crediti di carbonio. Forest@ 8:149-161. doi:10.3832/efor0672-008

Bernetti I, Romano S (2007) Economia delle risorse forestali. Liguori Editore, Napoli

Bernetti I, Ciampi C, Fagarazzi C, Sacchelli S (2010) L'impatto dei cambia-menti climatici sul settore produttivo forestale toscano: stima dei danni economici nel periodo 2007-2099. Ital J For Mt Environ 65:281-297. doi:10.4129/ifm.2010.3.02 
Bonomi A, Droghei G, Lumicisi A (2009) Lo schema EU-ETS ed i crediti forestali: analisi di possibili scenari per il periodo 2013-2020. Forest@ 6:349-356. doi:10.3832/efor0601-006

Cantiani M (1957) Il prezzo di macchiatico del travame "uso Trieste" a Vallombrosa. Ital J For Mt Environ 2:100

Carraro C, Crimi J, Sgobbi A (2007) La valutazione economica degli impatti dei cambiamenti climatici in Italia e delle relative misure di adattamento. Agenzia per la Protezione dell'Ambiente e per i servizi Tecnici (APAT). https://www.google.it/?gws_rd=ssl\#q=Ada ptation+of+forest+and+people+to+climate+change.+A+global+assessment+report. Accessed 14 Oct 2014

Cozzi M, Di Napoli F, Viccaro M, Romano S (2013) Use of forest residues for building forest biomass supply chains: technical and economic analysis of the production process. Forests 4:1121-1140. doi:10.3390/f4041121

Deng Y, Sadiq R, Jiang W, Tesfamariam S (2011) Risk analysis in a linguistic environment: a fuzzy evidential reasoning-based approach. Expert Syst Appl 38:15438-15446. doi:10.1016/j. eswa.2011.06.018

Donat MG, Alexander LV, Yang H, Durre I, Vose R, Dunn RJH et al (2013) Updated analyses of temperature and precipitation extreme indices since the beginning of the twentieth century: the HadEX2 dataset. J Geophys Res Atmos 118:2098-2118. doi:10.1002/jgrd.50150

Ducey MJ (2001) Representing uncertainty in silvicultural decisions: an application of the Dempster-Shafer theory of evidence. For Ecol Manage 150:199-211. doi:10.1016/S03781127(00)00565-Xemission/index.php?idp=0, accessed 24 Oct 2014

Federici S, Vitullo M, Tulipano S, De Laurentis R, Seufert G (2008) An approach to estimate carbon stocks change in forest carbon pools under the UNFCCC: the Italian case. iForest 1:86-95. doi:10.3832/ifor0457-0010086final-draft_postplenary_full.pdf, Accessed 18 Nov 2014

Fu WJ, Jiang PK, Zhou GM, Zhao KL (2014) Using Moran's and GIS to study the spatial pattern of forest litter carbon density in a subtropical region of south-eastern China. Biogeosciences 11:2401-2409. doi:10.5194/bg-11-2401-2014

Giorgi F, Lionello P (2008) Estimated from high resolution simulations with a regional climate model. Global Planet Change 62:195-209

Hamilton K, Peters-Stanley M, Marcello T, Sjardin M (2011) Back to the future. State of the voluntary Carbon Markets 2011. Ecosystem Marketplace \& Bloomberg New Energy Finance. http://www.forest-trends.org/documents/files/doc_2828.pdf. Accessed 11 Nov 2014

Hanley J, Caballero R (2012) The role of large-scale atmospheric flow and Rossby wave breaking in the evolution of extreme windstorms over Europe. Geophys Res Lett 39, L21708. doi:10. 1029/2012GL053408

INEA (2012) L'agricoltura italiana conta 2012. http://dspace.inea.it/bitstream/inea/343/1/2023. pdf. Accessed 5 Nov 2014

IPCC (1997) The regional impacts of climate change: an assessment of vulnerability. Cambridge University Press, New York

IPCC (2003) Good practice guidance for land use, land-use change and forestry. Penman J, Gytarsky M, Hiraishi T, Krug T, Kruger D, Pipatti R, Buendia L, Miwa K, Ngara T, Tanabe K, Wagner F. IGES, Kanagawa, Japan

IPCC (2006) Agriculture, forestry and other land use. In: Eggleston S, Buendia L, Miwa K, Ngara T, Tanabe K (eds) Guidelines for national greenhouse gas inventories. IGES, Kanagawa

IPCC (2007) Climate change 2007. The AR4 synthesis report. http://www.ipcc.ch/publications_ and_data/ar4/syr/en/main.html. Accessed 11 Nov 2014

IPCC (2014) Climate change 2014: mitigation of climate change. Contribution of working group III to the fifth assessment report of the intergovernmental panel on climate change. http:// report.mitigation2014.org/drafts/final-draft-postplenary/ipcc_wg3_ar5_

Jacobeit J, Hertig E, Seubert S, Lutz K (2014) Statistical downscaling for climate change projections in the Mediterranean region: methods and results. Reg Environ Change 14:1891-1906. doi:10.1007/s10113-014-0605-0 
Malczewski J (2004) GIS-based land-use suitability analysis: a critical over-view. Prog Plann 62:3-65. doi:10.1016/j.progress.2003.09.002

Maron JL, Baer KC, Angert AL (2014) Disentangling the drivers of context-dependent plantanimal interactions. J Ecol 102:1485-1496. doi:10.1111/1365-2745.12305

Merlo M (1991) Elementi di economia ed estimo forestale-ambientale. Pàtron editore, Bologna

Nakićenović N, Alcamo J, Davis G, de Vries B, Fenhann J, Gaffin S, Gregory K et al (2000) IPCC special report on emissions scenarios (SRES). Cambridge University Press, New York, http:// www.ipcc.ch/ipccreports/sres/

Nijnik M, Miller D (2013) Targeting sustainable provision of forest ecosystem services with special focus on carbon sequestration. In: Matyssek R, Clarke N, Mikkelsen TN, Tuovinen JP, Wieser G, Paoletti E (eds) Climate change, air pollution and global challenges-understanding and perspectives from forest research. Elsevier, Oxford, pp 547-568

Patrone G (1947) Osservazione sul calcolo del prezzo di macchiatico. Ital J For Mt Environ 5:111-114

Robert G (2008) Policies and instruments for the adaptation of forest and the forest sector to impacts of climate change as indicated in United Nations frame-work convention on climate change national reports. IUFRO Occasional paper $n^{\circ} 22$, Vienna

Rojas M, Li LZ, Kanakidou M, Hatzianastassiou N, Seze G, Le Treut H (2013) Winter weather regimes over the Mediterranean region: their role for the regional climate and projected changes in the twenty-first century. Clim Dyn 41:551-571. doi:10.1007/s00382-013-1823-8

Romano S, Cozzi M, Di Napoli F, Viccaro M, Targetti Ferri S (2013) Biomasses as an opportunity for local development: techno-economic analysis for the Basilicata region, Italy. Paper presented at the 43rd incontro di studi Ce.S.E.T on the Sviluppo economico e nuovi rapport tra agricoltura, territorio e ambiente, Verona, Italy, 21-23 November 2013

Saaty TL (1988) Multicriteria decision making — the analytic hierarchy process: planning, priority setting, resource allocation. RWS, Pittsburgh

Seppälä R, Buck A, Ktila P (eds) (2009) Adaptation of forest and people to climate change. A global assessment report. IUFRO World Series, vol 22, Esa-Print Oy, Tampere

Serpieri A (1917) Osservazioni sul prezzo di macchiatico. L'Alpe IV 3:76-82

Shafer G (1976) A mathematical theory of evidence. Princeton University Press, New York

Vitullo M, De Laurentis R, Federici S (2007) La contabilità del carbonio con-tenuto nelle foreste italiane. Silvae anno III n 9:91-104

Yousefpour R, Temperli C, Bugmann H, Elkin C, Hanewinkel M, Meilby H, Jacobsen JB, Thorsen BJ (2013) Updating beliefs and combining evidence in adaptive forest management under climate change: a case study of Norway spruce (Picea abies L. Karst) in the Black Forest, Germany. J Environ Manage 122:56-64. doi:10.1016/j.jenvman.2013.03.004

Zadeh LA (1987) Fuzzy sets and applications. Wiley-Interscience, New York 